Pak. j. sci. ind. res. Ser. B: biol. sci. 2021 64B(2) 136-141

\title{
Effect of Copper Chloride on the Growth of Maize (Zea mays)
}

\author{
Mujahid Hussain ${ }^{\mathrm{a}}$, Abdul Ghania ${ }^{\mathrm{a}}$, Amna Imtiaz ${ }^{\mathrm{a}}$, Muhammad Imrana, Abdul Majid ${ }^{\mathrm{a}}$, \\ Muhammad Ikramb ${ }^{b}$, Muhammad Nadeem ${ }^{c}$, Hira Fatimad and Mubashar Hassan ${ }^{\mathrm{e}}$ \\ ${ }^{a}$ Department of Botany, University of Sargodha, Sargodha, Punjab, Pakistan \\ ${ }^{b}$ Department of Botany, PMAS Arid Agriculture University, Rawalpindi, Punjab-46300, Pakistan \\ ${ }^{c}$ Institute of Food Science and Nutrition, University of Sargodha, Sargodha, Punjab, Pakistan \\ ${ }^{\mathrm{d}}$ Department of Botany, The University of Lahore, Sargodha, Pakistan \\ ${ }^{\mathrm{e}}$ Department of Zoology, University of Sargodha, Sargodha, Punjab, Pakistan
}

(received September 13, 2018; revised May 6, 2019; accepted May 9, 2019)

\begin{abstract}
Maize is an important cereal crop which is directly eaten by humans. The present study was conducted to access the effect of copper chloride on the growth of Zea mays plant. The experiment was carried out in pots. Different concentration of copper chloride ( 0 ppm as control, $25 \mathrm{ppm}, 50 \mathrm{ppm}, 75 \mathrm{ppm})$ were applied to plant before germination and after two weeks of germination. The results showed that there is decreased in growth of Zea mays takes place, while the highest biomass above ground ( $3.63 \pm 0.2 \mathrm{~g}$, $0.29 \pm 0.005 \mathrm{~g})$, biomass below ground $(2.26 \pm 0.15 \mathrm{~g}, 0.08 \pm 0.005 \mathrm{~g})$ total biomass $(5.90 \pm 0.20 \mathrm{~g}, 0.29 \pm 0.005$ g) fresh and dry respectively were noted at control. Maximum shoot length $(27.86 \pm 1.07 \mathrm{~cm})$, root length $(2.46 \pm 0.15 \mathrm{~cm})$, leaf length $(27.93 \pm 0.56 \mathrm{~cm})$, leaf width $(3.13 \pm 0.30 \mathrm{~cm})$, leaf area $\left(65.72 \pm 7.68 \mathrm{~cm}^{2}\right)$, number of leaves $(9.0 \pm 1.0)$, number of seeds germinate $(10.0 \pm 0.50)$ were also noted at control level.
\end{abstract}

Keywords: Zea mays, growth, copper chloride

\section{Introduction}

Plants in both natural and agricultural settings are continuously exposed to many types of abiotic and biotic stresses such as drought, salinity. Salinity is a most major abiotic stress factor, which affecting the seed germination and plant growth by disturbing their series of morphological, physiological and metabolic processes (Jamian et al., 2014; Suzuki et al., 2014). It also causes molecular changes in plant growth and is one of the most common factor of reduced crop production (Karmoker et al., 2008). Salinity stress is continuously increasing in semi-arid and arid areas on the earth. Semi-arid and arid lands represent almost $40 \%$ of the area on the earth's (Foster et al., 2018). Many higher plant species including most crops are subjected to growth inhibition under high salt condition. Salt inhibit the plant growth is not only by disturbing osmotic ion balance but also effect the water uptake, cell metabolism (Hussain et al., 2010). Reduction in growth of plant may also be attributed to severe effects of salinity on various biochemical and physiological process (Majeed et al., 2010). It may be due to minimizing the uptake of other minerals such as $\mathrm{Ca}^{2+}$, $\mathrm{K}^{+}, \mathrm{Na}^{+}$(Ashraf, 2004). Salinity affect the plants by two ways: the salt in the soil decreases the water availability to roots known as osmotic stress and the

*Author for correspondence;

E-mail: mujahid.hussain7877@gmail.com salt which is absorbed by plants can concentrate in their roots, stems and leaves to dangerous levels in certain tissues known as ion stress (Munns et al., 1995). Reduction in growth under salty condition may due to alteration of several physiological processes which includes the change in ion balance concentration, stomatal behaviour, water status, mineral nutrition, photosynthetic efficiency, carbon utilization and allocation (Munns and Termaat, 1986).

Copper chloride is also belonging to salt. Excess of copper may be occurring in soil due to many anthropogenic activities i.e. sewage sludge, mine slag, application of copper containing fertilizers, fungicides, bactericides. Symptoms of copper toxicity in plants is similar salinity stress (Sonmez et al., 2006), while in Pakistan, maize is one of the most important crop used as fodder for animals, also used for preparation of poultry food, serves as food, corn oil for human, also used as raw material for agriculturebased industries. Maize is comparatively insidious to salty irrigation water and showing up to $50 \%$ reduction in vintage at 3.9dS mG $\mathrm{d}^{1} \mathrm{EC}$ (Shahzad et al., 2012; Ullah et al., 2010). According to many reports, maize is sensitive at early stages but can stand under salt stress at latter stage growth. Literature also revealed that excess of copper in soil causes adverse effect on morphology, physiology and anatomy of maize (Khatoon et al., 2010). Salinity stress also disturbs the uptake and accumulation of essential nutrients (Usman et al., 2012). 
In review of the above literature, the objective of the study is to assess the effect of copper chloride on the growth of maize.

\section{Materials and Methods}

The plant used for this experiment was Zea mays. The seeds of Zea mays were acquired from Ghala Mandi, Sargodha. The experiment was performed in pots with three replicates. Every pot was filled with $6 \mathrm{Kg}$ of mixed loamy soil. We took equal sized pots for the purpose of experiment. The four treatments of copper chloride were applied on plants before germination and after two weeks of germination. Twelve seeds were grown per pot. The pots were irrigated with tap water as and when required. The data was taken after four weeks after emergence. Fresh samples were collected by pulling carefully from soil to avoid damage to the roots, shoots and leaves. Collected samples were washed away with distilled water to removes the soil particles attached with it and taken in a plastic bag for further analysis.

Copper treatments. Four levels of copper chloride were used in this experiment including control 1. $\mathrm{T} 1=$ Control $0 \mathrm{ppm} ; 2$. $\mathrm{T} 2=25 \mathrm{ppm} ; 3$. T3 $=50 \mathrm{ppm}$; 4. $\mathrm{T} 4=75 \mathrm{ppm}$

Morphological attributes (growth parameters). Weight (g). After sampling the fresh and dry weight of plant (above ground, below ground) were taken by using electrical balance.

Length (cm). Shoot length, root length, leaf length and leaf width of the plant was measured manually in $\mathrm{cm}$ with the help of scale.

Leaf area $\left(\mathrm{cm}^{2}\right)$. Leaf area was measured in $\mathrm{cm}^{2}$ with the help of formulae

Leaf area $=$ Leaf length $\times$ Leaf width $\times \mathrm{CF}$

Number of leaves per plant and seeds germinate. Number of leaves of each plant and number of seeds germinate for each pot were counted manually.

Statistical analysis. Statistical analysis was carried out using Microsoft Excel (Steel et al., 1997).

\section{Results and Discussion}

Data regarding morphological attributes of maize crop as affected by copper stress showed that there is reduction in fresh and dry weight of plant occur as the concentration of metal increases in soil, while shoot and root fresh and dry weight were varied from
$2.40 \pm 0.01,1.36 \pm 0.005,0.24 \pm 0.01,0.02 \pm 0.01$ to $2.93 \pm 0.15,1.80 \pm 0.1,0.28 \pm 0.01,0.08 \pm 0.01 \mathrm{~g}$ respectively which is shown below in the Table 1 and Fig. 1, 2, 4, 5. However, the maximum total biomass of plant was measured in $\mathrm{T} 1$ as $5.90 \pm 0.20$ and $0.37 \pm 0.005 \mathrm{~g}$ fresh and dry respectively which is shown in Fig. 3 and 6. Our results are in collaboration with the findings of (Usman et al., 2012). Their findings showed the morphological responses of maize against $\mathrm{NaCl}$ that maize plant show sensitive response against salt stress. As the salinity levels goes on increasing gradually, it greatly reduced the growth parameters. Similar results were also observed by Cramer et al. (1994) and Hasan et al. (2018). Findings of Dionisio-Sese et al. (2000) also showed that salt stress cause reduction in plant development either by increasing plant osmotic potential or may be attributed to specific ion toxicity.

Biomass above ground (g) Fresh

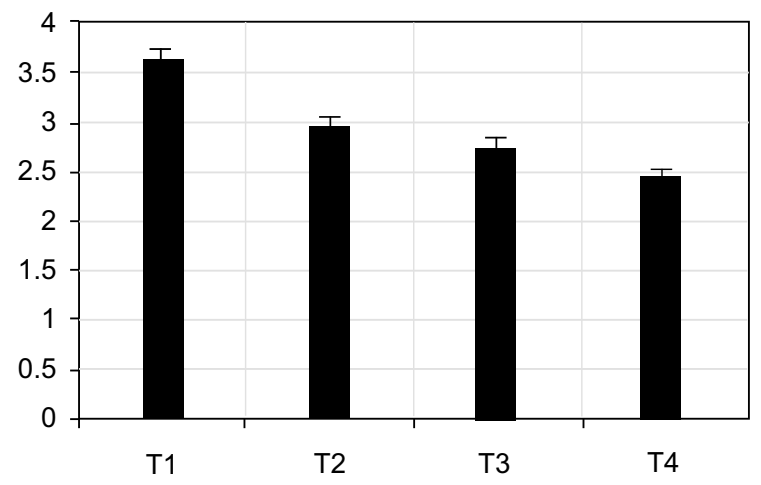

Fig. 1. Effect of copper chloride on shoot fresh weight of Zea mays.

Biomass above ground (g) Fresh

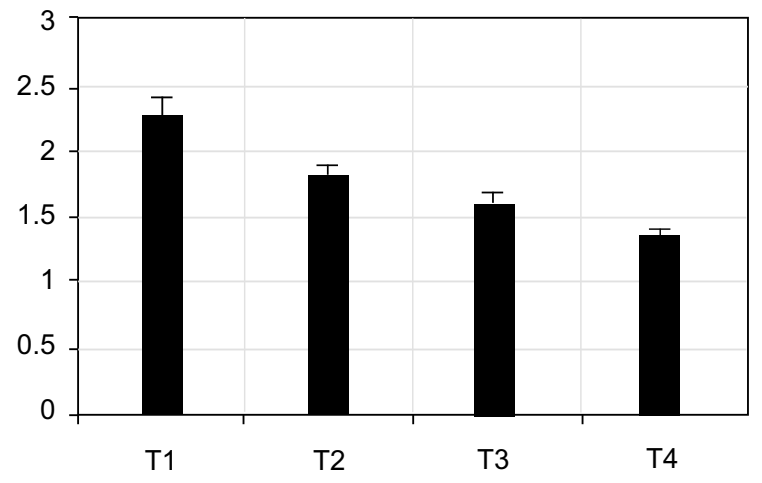

Fig. 2. Effect of copper chloride on Root fresh weight of Zea mays. 
Data regarding plant height and root length of maize crop as affected by copper stress showed that there is decreased in shoot and root length of plant occur. However, it varies from $27.86 \pm 1.07,2.46 \pm 0.15$ to $18.83 \pm 0.61 \mathrm{~cm}, 1.26 \pm 1.33 \mathrm{~cm}$ which is shown in Fig. 7 and 8 respectively. The maximum shoot and root length was noted at control (T1), while minimum was noted at T4 level shown in Table 1. This reduction is due to toxicity of the copper chloride. Similar findings were noted by Usman et al. (2012) when applied salt stress $(\mathrm{NaCl})$ to maize. Outcomes of Ghoulam et al. (2001) also showed that salinity caused a significant reduction in growth parameters (root, shoot fresh and dry weight, root and shoot length, leaf area) of sugar beet plants.

Data regarding leaves of maize crop as affected by copper stress showed that copper chloride also have

Total Biomass (g) Fresh

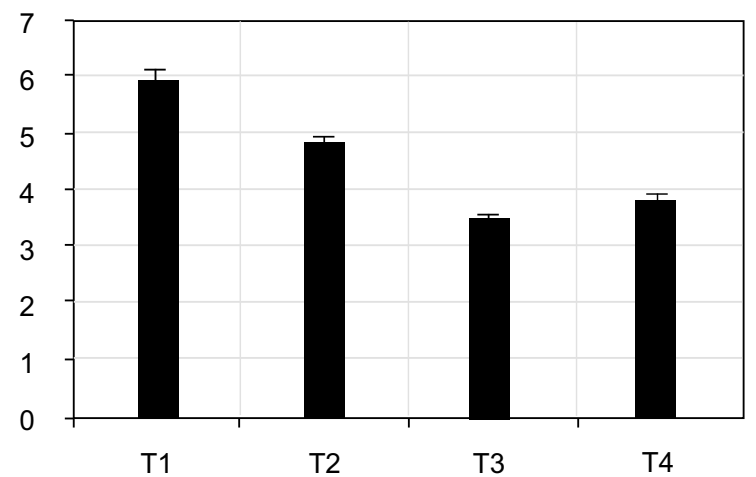

Fig. 3. Effect of copper chloride on total fresh weight of Zea mays.

Biomass above ground (g) Dry

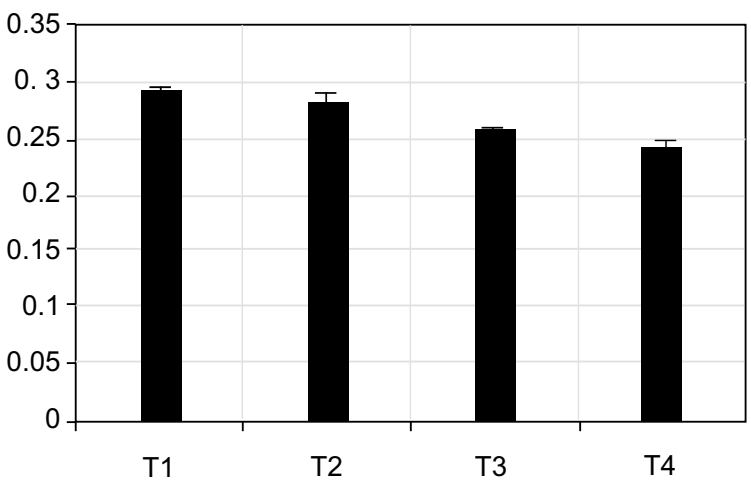

Fig. 4. Effect of copper chloride on shoot dry weight of Zea mays. negative effect on leaves. However, leaf length, leaf width, leaf area and number of leaves per plant ranged from $27.93 \pm 0.56,3.13 \pm 0.30,65.72 \pm 7.68,9.0 \pm 1.0$, to $14.96 \pm 1.33 \mathrm{~cm}, 1.33 \pm 0.05 \mathrm{~cm}, 15.01 \pm 2.0 \mathrm{~cm}^{2}, 7.0 \pm 1.0$ respectively, while the maximum growth of leaves (Leaf length, leaf width, leaf area and number of leaves per plant) was observed in T1. Leaf length, leaf width, leaf area and number of leaves per plant also reduced under salt stress which also lead to reduction in yielding components of plants i.e. nutritional contents which is shown below in Fig. 9, 10, 12, 11 respectively. Results showed the reduction of leaf area takes place gradually as the concentration of metal increasing. Leaf growth is the most affected parameter by salt stress as earlier also explained by Usman et al. (2012). Dale (1998) also showed that leaf area of plant decreases due to salinity which play important role in photosynthesis, decreasing due to decreasing in chlorophyll contents,

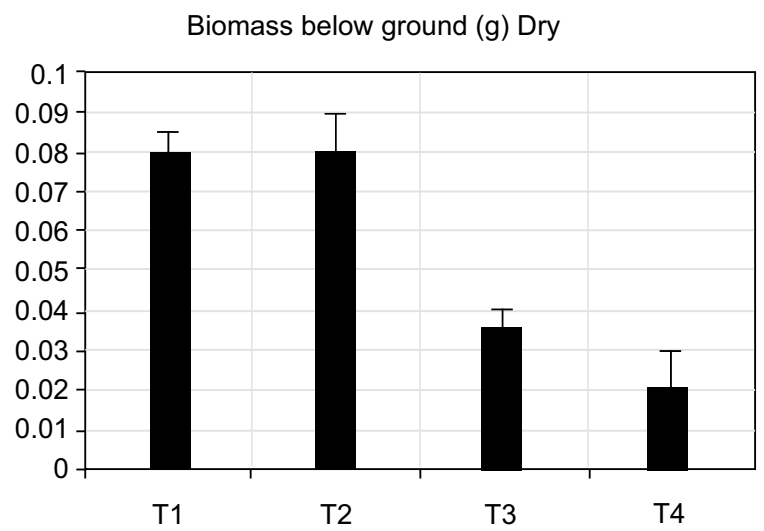

Fig. 5. Effect of copper chloride on root dry weight of Zea mays.

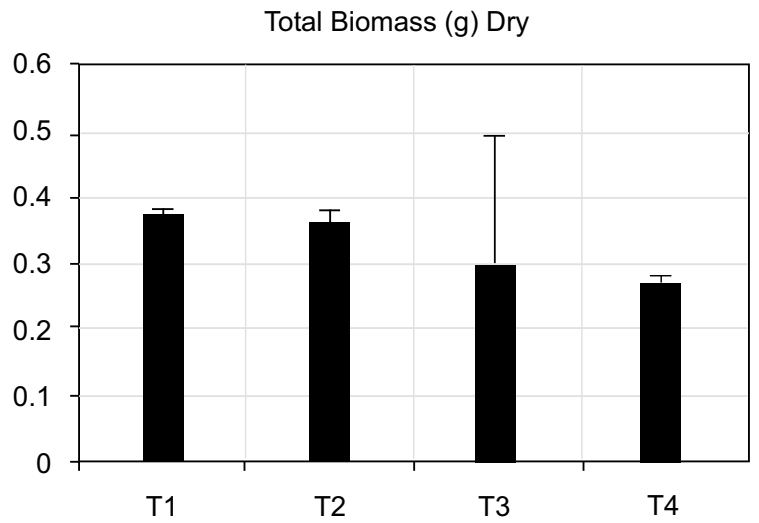

Fig. 6. Effect of copper chloride on total dry weight of Zea mays. 


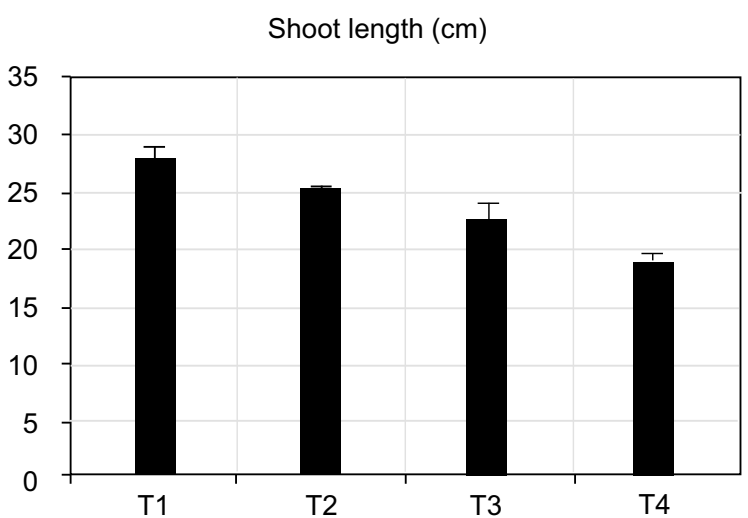

Fig. 7. Effect of copper chloride on shoot length of Zea mays.

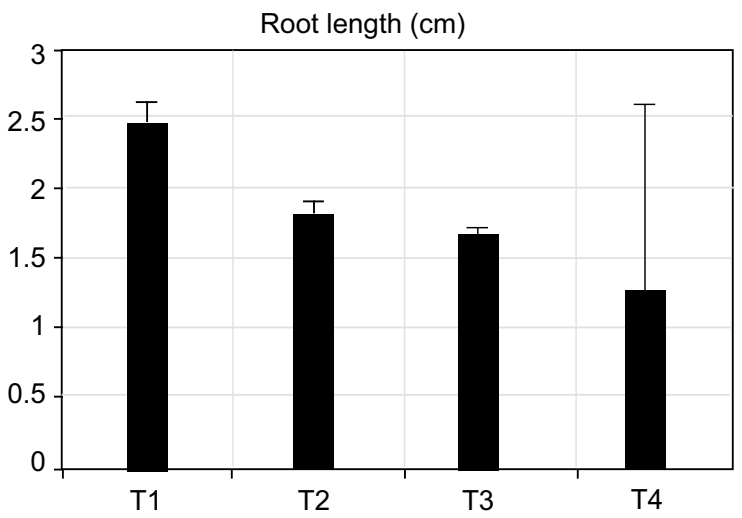

Fig. 8. Effect of copper chloride on root length of Zea mays.

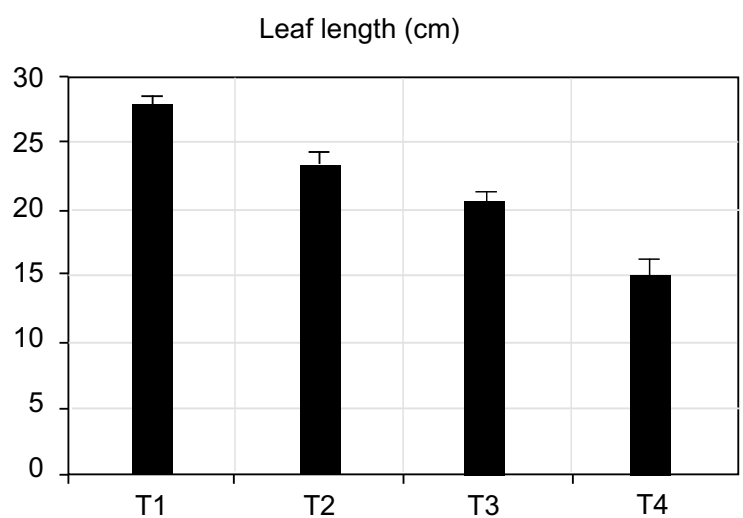

Fig. 9. Effect of copper chloride on leaf length of Zea mays.

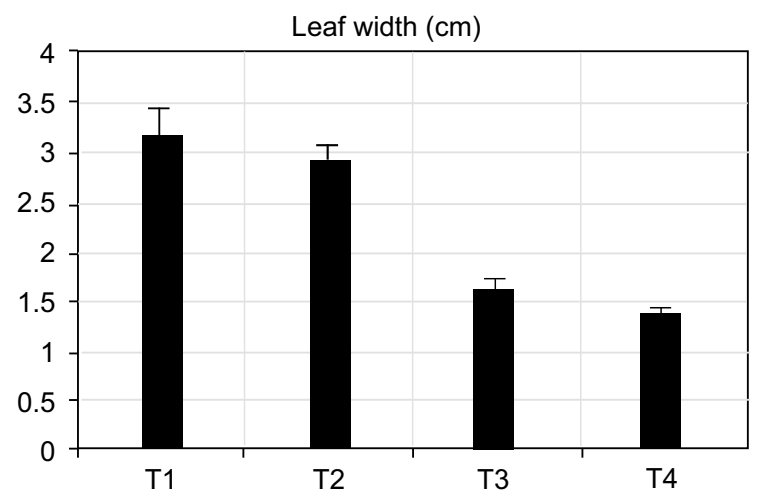

Fig. 10. Effect of copper chloride on leaf width of Zea mays.

Table 1. Shows the variation in morphological attributes of Zea mays under different level of copper chloride treatment

\begin{tabular}{lllll}
\hline \hline Parameters & \multicolumn{4}{c}{ Treatments } \\
\cline { 2 - 5 } & $\mathrm{T} 1$ & $\mathrm{~T} 2$ & $\mathrm{~T} 3$ & $\mathrm{~T} 4$ \\
\hline Fresh biomass above ground $(\mathrm{g})$ & $3.63 \pm 0.20$ & $2.93 \pm 0.15$ & $2.73 \pm 0.05$ & $2.4 \pm 0.01$ \\
Fresh biomass below ground $(\mathrm{g})$ & $2.26 \pm 0.15$ & $1.8 \pm 0.10$ & $1.60 \pm 0.10$ & $1.36 \pm 0.005$ \\
Total fresh biomass $(\mathrm{g})$ & $5.90 \pm 0.20$ & $4.73 \pm 0.15$ & $3.44 \pm 0.05$ & $3.76 \pm 0.11$ \\
Dry biomass above ground $(\mathrm{g})$ & $0.29 \pm 0.005$ & $0.28 \pm 0.01$ & $0.26 \pm 0.01$ & $0.24 \pm 0.01$ \\
Dry biomass below ground $(\mathrm{g})$ & $0.08 \pm 0.005$ & $0.08 \pm 0.01$ & $0.036 \pm 0.005$ & $0.02 \pm 0.01$ \\
Total dry biomass $(\mathrm{g})$ & $0.37 \pm 0.005$ & $0.36 \pm 0.20$ & $0.29 \pm 0.20$ & $0.26 \pm 0.02$ \\
Shoot length $(\mathrm{cm})$ & $27.86 \pm 1.07$ & $25.26 \pm 0.15$ & $22.67 \pm 1.45$ & $18.83 \pm 0.61$ \\
Root length (cm) & $2.46 \pm 0.15$ & $1.8 \pm 0.10$ & $1.66 \pm 0.05$ & $1.26 \pm 1.33$ \\
Leaf length (cm) & $27.93 \pm 0.56$ & $23.3 \pm 0.85$ & $20.6 \pm 0.70$ & $14.96 \pm 1.33$ \\
Leaf width (cm) & $3.13 \pm 0.30$ & $2.87 \pm 0.20$ & $1.56 \pm 2.0 .15$ & $1.33 \pm 0.05$ \\
Leaf area (cm $\left.{ }^{2}\right)$ & $65.72 \pm 7.68$ & $50.12 \pm 4.58$ & $26.61 \pm 2.22$ & $15.01 \pm 2.0$ \\
Number of leaves & $9.0 \pm 1.0$ & $8.0 \pm 1.0$ & $8.0 \pm 1.0$ & $7.0 \pm 1.0$ \\
Number of seeds germinate & $10.0 \pm 0.50$ & $9.0 \pm 0.50$ & $8.0 \pm 0.5$ & $7.0 \pm 0.5$ \\
\hline \hline
\end{tabular}


reduction in photosynthetic rate, plant growth activity and metabolism, ultimately lead to stunted growth in plants (Hasan et al., 2018).

Data regarding seed germination of maize crop as affected by copper stress showed seed germination of maize also affected with the excessive amount of copper chloride in soil while the maximum number of seeds germination $(10.0 \pm 0.50)$ was noted in $\mathrm{T} 1$ which is shown in Fig. 13. Similar results were also found by (Singh et al., 2011; Sfaxi-Bousbih et al., 2010). They showed that copper has negative effects on maize and is found to be toxic for plant germination. $\mathrm{Cu}$ presence in soil lead to oxidative stress by the generation of ROS (Reactive Oxygen Species) and by the reduction in CAT activity (catalase) by the oxidation of protein structure (Pena et al., 2011). Cu stress lead to reduction of germination rate and brings biomass mobilization by the releasing of fructose and glucose thus constraining

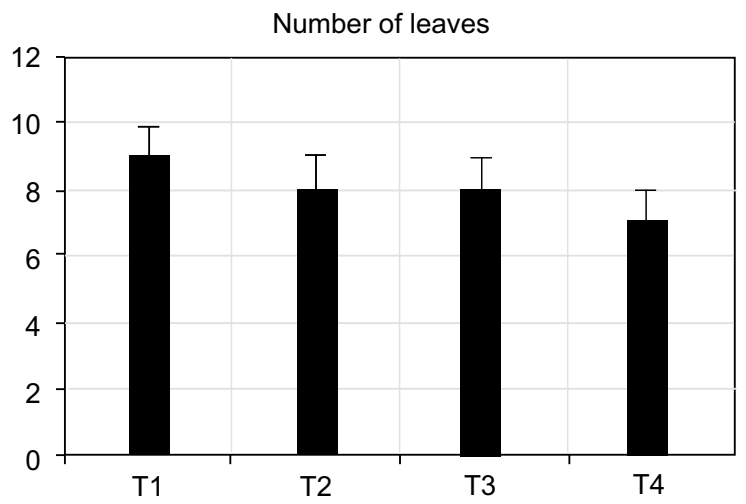

Fig. 11. Effect of copper chloride on number of leaves of Zea mays.

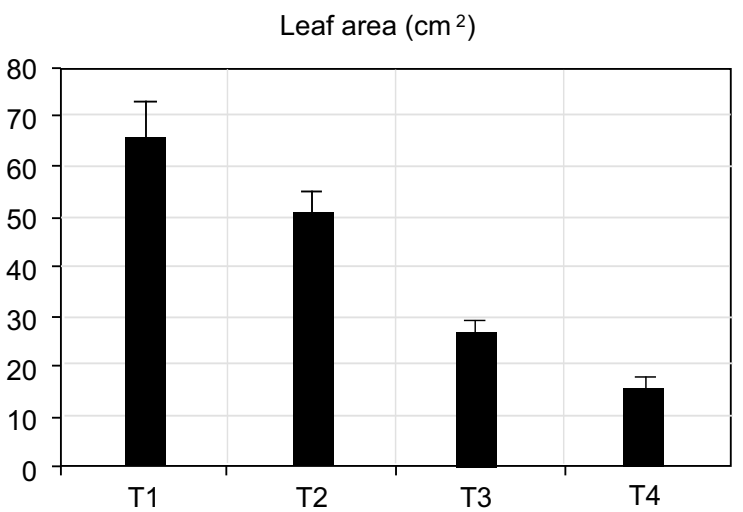

Fig. 12. Effect of copper chloride on leaf area of Zea mays.

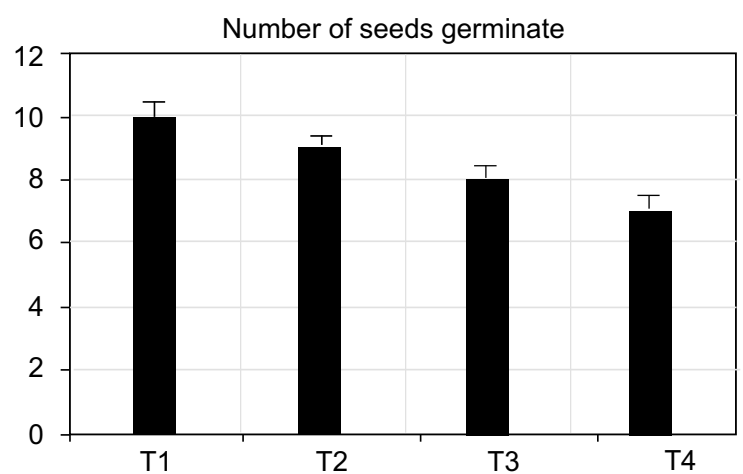

Fig. 13. Effect of copper chloride on number of seeds germinate of Zea mays.

the breakdown of sucrose and starch in stored tissues by disturbing in the activities of alpha-amylase and invertase isoenzymes.

It is clear from the study that the seedling and growth of Zea mays decreased with the excessive amount of copper chloride with the passage of time. So, copper chloride has negative effects on the seeding and growth of Zea mays plant. It will cause inhibition in seeding and the growth of Zea mays.

Conflict of Interest. The authors declare no conflict of interest.

\section{References}

Ashraf, M. 2004. Some important physiological selection criteria for salt tolerance in plants. FloraMorphology, Distribution, Functional Ecology of Plants, 199: 361-376.

Cramer, G.R., Alberico, G.L., Schmidt, C. 1994. Leaf expansion limits dry matter accumulation of Salt Stressed maize. Functional Plant Biology, 21: 663674.

Dale, J.E. 1998. The control of leaf expansion. Annual Reviews in Plant Physiology and Plant Molecular Biology, 9: 267-295.

Dionisio-Sese, M.L., Tobia, S. 2000. Effect of Salinity on sodium content and photosynthetic responses of rice seedling differing in salt tolerance. Journal of Plant Physiology, 157: 54-58.

Foster, S., Pulido-Bosch, A., Vallejos, Á., Molina, L., Llop, A., MacDonald, A.M. 2018. Impact of irrigated agriculture on groundwater-recharge salinity: a major sustainability concern in semiarid regions. Hydrogeology Journal, 26: 27812791. 
Ghoulam, C., Ahmed, F., Khalid, A. 2001. Effects of salt stress on growth, inorganic ions and proline accumulation in relation to osmotic adjustment in five sugar beet cultivars. Environmental and Experimental Botany, 47: 139-150.

Hasan, R., Kawasaki, M., Taniguchi, M., Miyake, H. 2018. The damage of root, leaf and chloroplast ultrastructure on maize seedlings caused by salinity stress. In IOP conference series: Earth and Environmental Sciences, 197: 1-6.

Hussain, K., Nisar, M.F., Majeed, A., Nawaz, K., Bhatti, K.H., Afghan, S., Shahzad, A., Hussnain, S.Z. 2010. What molecular mechanism is adapted by plants during salt stress tolerance. African Journal of Biotechnology, 9: 416-422.

Jamian, S.S., Mehrani, S., Asilian, K.S., Tabrizi, A.T., Goharian, A. 2014. The effects of salinity on seed germination and seedling growth of three medicinal plants. International Journal of Farming and Allied Sciences, 3: 299-303.

Karmoker, J.L., Farhana, S., Rashid, P. 2008. Effect of salinity on ion accumulation in maize (Zea mays). Bangladesh Journal of Botany, 37: 203-205.

Khatoon, T., Hussain, K., Majeed, A., Nawaz, K., Nisar, M.F. 2010. Morphological variations in maize (Zea mays) Under different levels of $\mathrm{NaCl}$ at the germinating stage. World Applied Sciences Journal, 8: 1294-1297.

Majeed, A., Nisar, M.F., Hussain, K. 2010. Effect of Saline culture on the concentration of $\mathrm{Na}, \mathrm{K}$ and $\mathrm{CIG}$ in Agrostis tolonifera. Current Research Journal of Biological Sciences, 2: 76-82.

Munns, R., Termaat, A. 1986. Whole-plant responses to salinity. Functional Plant Biology, 13: 143-160.

Munns, R., Schachtman, D.P., Condon, A.G. 1995. The significance of the two-phase growth response to salinity in wheat and barley. Functional Plant Biology, 22: 561-569.
Pena, L.B., Azpilicueta, C.E., Gallego, S.M. 2011. Sunflower cotyledons cope with copper stress by inducing catalase subunits less sensitive to oxidation. Journal of Trace Elements in Medicine and Biology, 25:125-129.

Sfaxi-Bousbih, A., Chaoui, A., EI-Ferjani, E. 2010. Copper affects the cotyledonary carbohydrate status during the germination of bean seed. Biological Trace Element Research, 137: 110-116.

Shahzad, K., Shehzad, M.A., Iqbal, M., Arif, M. 2012. Response of maize (Zea mays L.) genotype to soil and foliar application of boron. Asian Journal of Pharmaceutical and Biological Research, 2: $65-$ 72.

Singh, H.P, Kaur, G., Batish, D.R., Kohli, R.K. 2011. Lead $(\mathrm{Pb})$-inhibited radicle emergence in Brassica campestris involves alterations in starchmetabolizing enzymes. Biological Trace Element Research, 144: 1295-1301.

Sonmez, S., Kaplan, M., Sonmez, N.K., Kaya, H., Uz, I. 2006. High level of copper application to soil and leaves reduce the growth and yield of tomato plants. Scientia Agricola., 63: 213-218.

Steel, R.G.D., Torrie, J.H., Dickey, D.A. 1997. Principles and Procedures of Statistics. A Biometrical Approach, 3rd Edition, McGraw Hill Book Co. New York, USA.

Suzuki, N., Rivero, R.M., Shulaev, V., Blumwald, E., Mittler, R. 2014. Abiotic and biotic stress combinations. New Phytologist., 203: 32-43.

Ullah, I., Ali, M., Farooqi, A. 2010. Chemical and nutritional properties of some maize (Zea mays L.) varieties grown in NWFP, Pakistan. Pakistan Journal of Nutrition, 9: 1113-1117.

Usman, M., Haq, A., Ahsan, T., Amjad, S., Riasat, Z., Umar, M. 2012. Effect of $\mathrm{NaCl}$ on Morphological Attributes of Maize (Zea mays L.). Botany Research International, 5: 57-60. 